\title{
The influence of diet on the weight and chemical constituents of the rat adrenal gland
}

\author{
By H. N. MUNRO, W. C. HUTCHISON, T. R. RAMAIAH AND \\ FRANCES J. NEILSON
}

\author{
Department of Biochemistry, University of Glasgow
}

(Received 7 December 1961-Revised I 3 March I962)

Although the response of the adrenal gland to excessive intakes of protein has been studied on many occasions (Fahr, I912; Tepperman, Engel \& Long, I943; Ingle, Ginther \& Nezamis, 1943; Ingle, I945; Benua \& Howard, I945; Leathem, I945, 1947, I95 I T Tuchmann-Duplessis, Aschkenasy-Lelu \& Aschkenasy, I948; Kovács \& Korpássy, 1952), there are few publications dealing with the effects of protein deficiency on the gland. In an early series of studies, Limson \& Jackson (I932) fed young rats for several months on a diet low in protein which inhibited growth; adrenal weight was reduced by $7 \%$, which was regarded as insignificant. Leathem (x958) found that the adrenal glands of immature rats fed for 30 days on a proteinfree diet were much smaller than the glands of rats fed for a similar period on a diet containing $20 \%$ of protein; however, this difference was inverted when the weights of the glands were expressed in relation to the final weights of the rats. In some unpublished experiments, Orton (1937) is reported by Tepperman et al. (I943) to have found no difference in the ratio of adrenal weight to body-weight between growing rats fed $a d l i b$. on a diet containing $3.5 \%$ protein and those on a diet containing I $8 \%$ protein. When calorie intake on the two diets was restricted to that consumed by the rats on the $3.5 \%$ protein diet, those on the $18 \%$ protein diet had larger adrenal glands. This experiment suggests that calorie intake may be a significant factor which modifies the response of the adrenal gland to dietary protein intake.

These experiments do not provide information about the influence of dietary protein level on individual chemical constituents of the adrenal gland, which may be affected independently of gross changes in gland weight. We have accordingly carried out experiments to determine the effect of complete removal of protein from the diet on the size of the adrenal gland and its content of protein, phospholipid and nucleic acids. Secondly, the possibility that calorie intake modifies the effect of dietary protein content on adrenal function has been examined. Thirdly, we have determined whether the response of the gland to the stimulus of adrenocorticotrophic hormone (ACTH) is affected by the protein and calorie content of the diet. The experiments carried out by previous investigators were confined to growing rats, usually fed on the diets over long periods, and in consequence the interpretation of the action of diet on adrenal weight in these experiments is complicated by large differences in body-weight between groups on different diets. Our experiments were; therefore, carried out on more 
mature animals and, for the same reason, were of short duration. A preliminary account of part of these experiments has already appeared (Hutchison, Ramaiah, Neilson \& Munro, 1960).

\section{EX PER I MEN T AL}

Animals and diets. Female albino rats, initially weighing $180-200 \mathrm{~g}$ in the 5 -day dietary experiment and I 50-I $80 \mathrm{~g}$ in the $\mathrm{I} I$-day experiment, were housed in individual cages under thermostatic conditions. The dietary arrangements were modelled on those used in previous experiments to provide different levels of protein and of calorie intake (Munro \& Naismith, 1953). The diets either contained an adequate amount of protein or were free from protein, and were given as two meals each day. At ro a.m. all animals received $\mathrm{I} g$ of a vitamin-mineral-roughage mixture (Munro, I949) and at 5 p.m. they ate a meal which provided all the protein of the diet. For rats allowed an adequate protein intake, this evening meal contained $2.4 \mathrm{~g}$ casein, $\mathrm{I} \cdot 4 \mathrm{~g}$ carbohydrate (equal parts of glucose and potato starch) and $0.4 \mathrm{~g}$ fat (margarine). For animals receiving the protein-free diet, all the casein of this meal was replaced by an isocaloric amount of carbohydrate. These basic diets provided $2 \mathrm{I} \mathrm{kcal} / \mathrm{rat}$ daily and in order to bring the calorie content up to any desired level, carbohydrate or fat was added to the morning meal.

During an initial 3 -day period all the animals were trained to accept the proteincontaining diet with $2.5 \mathrm{~g}$ glucose added to the morning meal. After this preliminary period of adjustment, half of the rats continued to receive the diet containing protein, while the others ate the protein-free diet. At each level of protein intake the animals were further subdivided into a group on a low intake of calories (2I kcal/day) and two groups on a high intake of calories ( $4 \mathrm{r} \mathrm{kcal} /$ day). The low-calorie intake was obtained by feeding the rats on the basic diets alone, and the high-calorie intake by including either $5 \mathrm{~g}$ of a mixture of starch and glucose $(5: \mathrm{I})$ or an isocaloric amount of olive oil $(2.5 \mathrm{ml})$ in the morning meal. These various diets were given for 5 days in the first experiment and I I days in the second experiment. The food offered was always fully consumed. During the last 3 days of each experiment, half of the rats in each dietary group were injected intramuscularly in the morning and in the evening with 5 i.u. ACTH (Cortrophin-ZN, Organon Laboratories Ltd).

Removal and analysis of adrenal glands. The rats were killed by stunning and bleeding and the adrenal glands were rapidly excised, cleaned of adhering tissue and weighed.

Chemical analysis of the glands was carried out by the modification of the procedure of Schmidt \& Thannhauser (1945) described by Munro \& Naismith (I953), the ribonucleic acid (RNA) being estimated finally as ribose and the deoxyribonucleic acid (DNA) as deoxyribose. After homogenization of the two glands in ice-cold water with a Potter-Elvehjem homogenizer the tissue was treated with cold $10 \%(\mathrm{w} / \mathrm{v})$ trichloroacetic acid and the precipitate was washed twice with cold trichloroacetic acid. The residue was then extracted successively with ethanol, twice with ethanol-chloroform $(3: I)$, then ethanol-diethyl ether $(3: I)$ and finally diethyl ether. These extracts were combined and their phosphorus content (lipid P) was determined by the procedure of Griswold, Humoller \& McIntyre (I95I). The air-dried residue left after ether 
extraction was incubated at $37^{\circ}$ for $17 \mathrm{~h}$ with $\mathrm{Iml} \mathrm{N}-\mathrm{NaOH}$; thereafter, a portion of the digest was taken for nitrogen determination by the method of Paul (I958). The value obtained for $\mathrm{N}$ content was corrected for nucleic acid $\mathrm{N}$ present in the digest, the corrected figure being taken as a measure of tissue protein N. No significant loss of protein occurred during the treatment with lipid solvents. The remainder of the alkaline digest was acidified with $\mathrm{HCl}$ and trichloroacetic acid to precipitate the DNA. After the precipitate had been washed twice with cold $5 \%(\mathrm{w} / \mathrm{v})$ trichloroacetic acid, the supernatant liquid and washings were combined to form the RNA fraction. The RNA content of the fraction was estimated by the orcinol procedure of Kerr \& Seraidarian (I945), the period of heating in the reagent being extended to $30 \mathrm{~min}$. The colour formed was compared with that from ribose, and expressed as RNA P on the assumption that $10 \mu \mathrm{g}$ ribose give the same colour intensity as $4^{\cdot} \mathrm{I} 3 \mu \mathrm{g}$ RNA P. The precipitate containing the DNA was dissolved in $\mathrm{N}-\mathrm{NaOH}$ and the amount of DNA was estimated by the method of Ceriotti (1952), with a calf thymus DNA preparation as standard; the results have been expressed as DNA P.

\section{RESULTS}

\section{Expt I. Five-day period of protein depletion}

The giving of a protein-free diet to rats leads within a few days to extensive losses of protein, phospholipid and RNA from the liver (Kosterlitz, I947). The effect of a

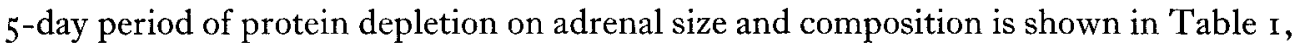

Table I. Expt I. Effects of protein deficiency and of adrenocorticotrophic hormone $(A C T H)$ administration on the weight and individual chemical components of the rat adrenal gland

(Diets providing an adequate amount of protein or free from protein were given for 5 days.

During the last 3 days, some rats at each level of protein intake were injected with 5 i.u. ACTH twice daily. Each entry is the mean result obtained with twenty-one rats. The standard deviations quoted come from the residual error variances obtained on analysis of variance of the results)

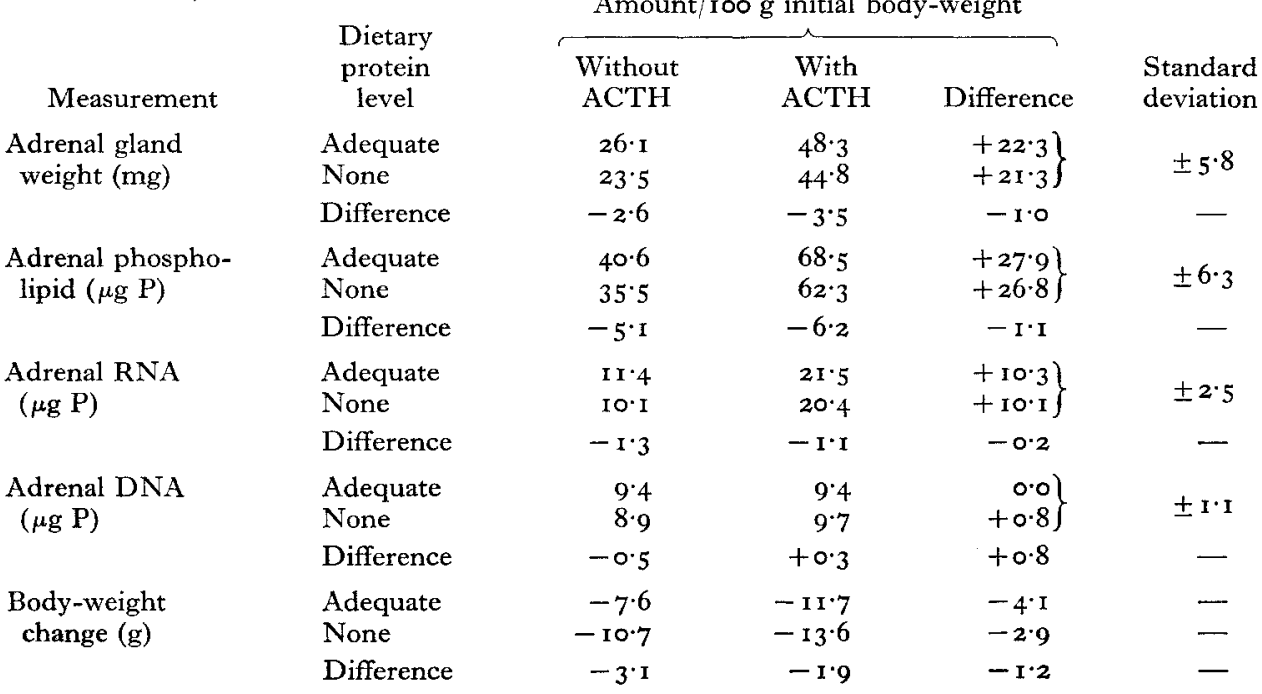


in which the results have been expressed as amounts/100 $\mathrm{g}$ initial body-weight, in order to minimize differences between individual animals at the beginning of the experiment. In this experiment no significant differences in the weight of the gland or in the amounts of its individual constituents resulted from giving the protein-free

Table 2. Expt 2. Effects of protein deficiency and of adrenocorticotrophic hormone $(A C T H)$ administration on the weight and individual chemical components of the rat adrenal gland

(Diets providing an adequate amount of protein or free from protein were given in combination with different levels of calorie intake for 1 I days. During the last 3 days, some rats on each diet were injected with 5 i.u. ACTH twice daily. Each entry is the mean result obtained with six rats in the uninjected groups and four rats in the ACTH-treated groups. The standard deviations quoted were computed from the residual error variances obtained on analysis of variance of the results)

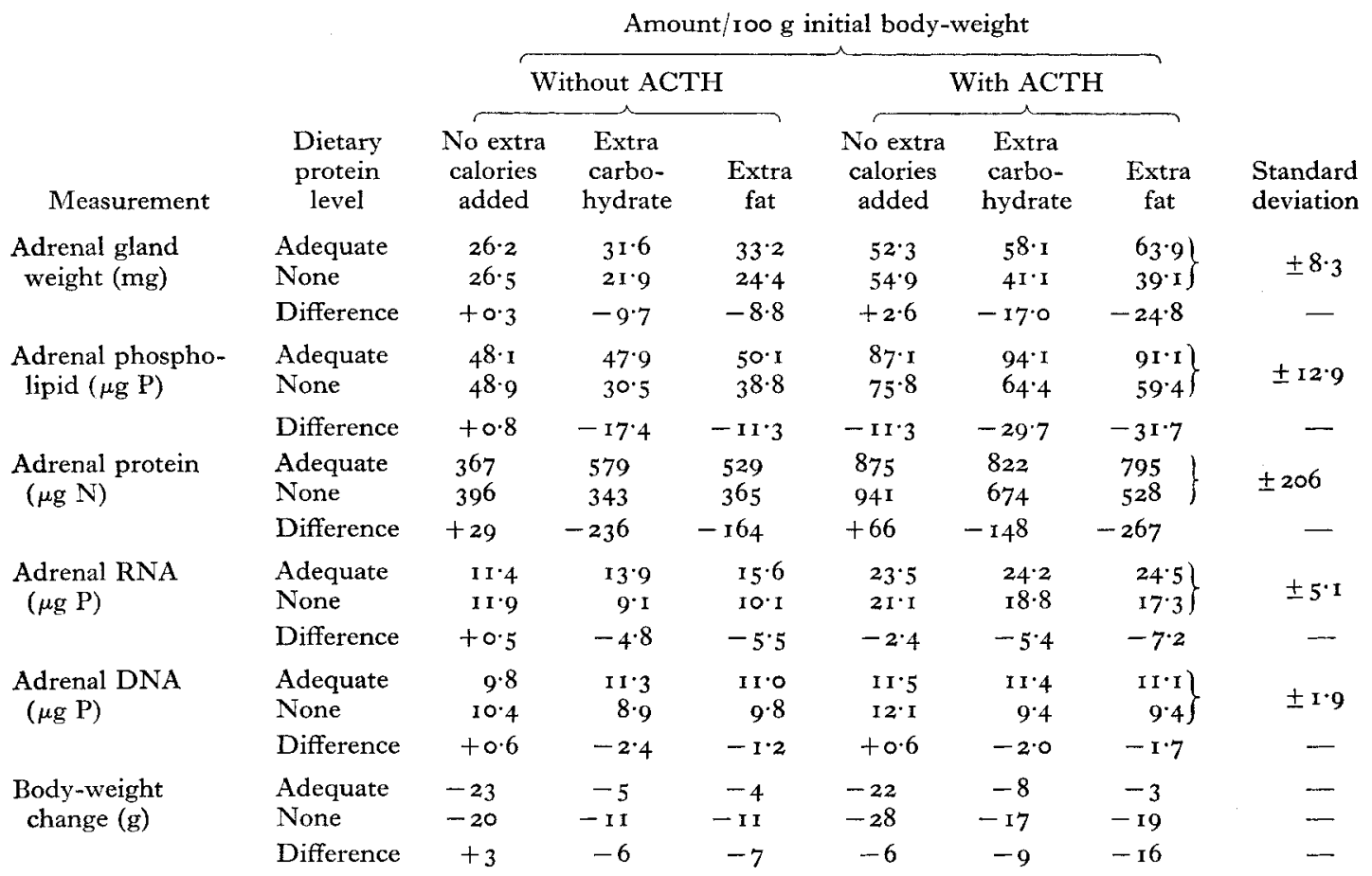

and protein-containing diets at different calorie levels. Consequently, the results obtained at each level of calorie intake have been combined in Table I. Analysis of variance of the values showed that the giving of the protein-free diet caused a significant reduction in gland weight $(P<0.02)$, in its total content of phospholipid $(P<$ $0.01)$ and of RNA $(P<0.05)$; the rats receiving the protein-free diet showed a $10-13 \%$ reduction of these constituents below the level of the control group receiving protein, whereas the difference in body-weight between the two groups of rats was only $3 \%$. The amount of DNA in the gland was not changed significantly $(P>0.05)$. Gland weight and the amounts of all constituents of the gland except DNA showed a significant increase $(P<0.01)$ after administration of ACTH. This response to ACTH administration was not influenced by diet $\left(P>0.0_{5}\right.$ for interaction). 


\section{Expt 2. Eleven-day period of protein depletion}

In this experiment, in which the period of protein deficiency was prolonged to I I days, significant effects of calorie intake on adrenal size and composition were obtained and are given in detail in Table 2. Analysis of variance of the values showed that absence of protein from the diet caused a highly significant $(P<0.0 \mathrm{I})$ reduction in gland weight and in the total amounts of phospholipid and of RNA in the gland; the total protein and DNA contents of the gland were also reduced significantly

\section{Table 3. Effects of protein deficiency and of adrenocorticotrophic hormone (ACTH) administration on the composition of the average rat adrenal cell}

(The values are from Expt 2. The gland weight and chemical components of the adrenal gland have been expressed in relation to the DNA of the tissue as a measure of cell number. The standard deviations quoted were computed from the residual error variances obtained on analysis of variance of the results)

\begin{tabular}{|c|c|c|c|c|c|c|c|c|}
\hline \multirow[b]{3}{*}{ Measurement } & \multirow[b]{3}{*}{$\begin{array}{c}\text { Dietary } \\
\text { protein } \\
\text { level }\end{array}$} & \multicolumn{6}{|c|}{ Amount/10 $\mu \mathrm{g}$ DNA P } & \multirow[b]{3}{*}{$\begin{array}{l}\text { Standard } \\
\text { deviation }\end{array}$} \\
\hline & & \multicolumn{3}{|c|}{ Without ACTH } & \multicolumn{3}{|c|}{ With ACTH } & \\
\hline & & $\begin{array}{c}\text { No extra } \\
\text { calories } \\
\text { added }\end{array}$ & $\begin{array}{c}\text { Extra } \\
\text { carbo- } \\
\text { hydrate }\end{array}$ & $\begin{array}{c}\text { Extra } \\
\text { fat }\end{array}$ & $\begin{array}{c}\text { No extra } \\
\text { calories } \\
\text { added }\end{array}$ & $\begin{array}{c}\text { Extra } \\
\text { carbo- } \\
\text { hydrate }\end{array}$ & $\begin{array}{c}\text { Extra } \\
\text { fat }\end{array}$ & \\
\hline \multirow{3}{*}{$\begin{array}{l}\text { Adrenal gland } \\
\text { weight }(\mathrm{mg})\end{array}$} & Adequate & $26 \cdot 6$ & $28 \cdot 5$ & $30 \cdot 0$ & $45 \cdot 3$ & 50.7 & $57 \cdot 6\}$ & \multirow{3}{*}{$\begin{array}{c} \pm 4 \cdot 4 \\
-\end{array}$} \\
\hline & None & $25 \cdot 7$ & $24: 7$ & $25 \cdot I$ & $45^{\cdot} \mathrm{I}$ & $43 \cdot 7$ & $4 I \cdot 6\}$ & \\
\hline & Difference & -0.9 & $-3 \cdot 8$ & -4.9 & -0.2 & -7.0 & $-16 \cdot 0$ & \\
\hline \multirow[t]{2}{*}{$\begin{array}{l}\text { Adrenal phospho- } \\
\text { lipid }(\mu \mathrm{g} \mathrm{P})\end{array}$} & $\begin{array}{l}\text { Adequate } \\
\text { None }\end{array}$ & $\begin{array}{l}45 \cdot 2 \\
48 \cdot 8\end{array}$ & $\begin{array}{l}43 \cdot 4 \\
37 \cdot 3\end{array}$ & $\begin{array}{l}45.9 \\
40.6\end{array}$ & $\begin{array}{l}75 \cdot 6 \\
62 \cdot 4\end{array}$ & $\begin{array}{l}82 \cdot 7 \\
68 \cdot 8\end{array}$ & $\left.\begin{array}{l}82 \cdot 3 \\
63 \cdot 2\end{array}\right\}$ & \multirow[t]{2}{*}{ $\pm 8 \cdot 6$} \\
\hline & Difference & $+3 \cdot 6$ & $-6 \cdot I$ & $-5 \cdot 3$ & -13.2 & -13.9 & $-I 9 \cdot r$ & \\
\hline \multirow[t]{2}{*}{$\begin{array}{l}\text { Adrenal protein } \\
(\mu \mathrm{g} \mathrm{N})\end{array}$} & $\begin{array}{l}\text { Adequate } \\
\text { None }\end{array}$ & $\begin{array}{l}390 \\
373\end{array}$ & $\begin{array}{l}490 \\
387\end{array}$ & $\begin{array}{l}472 \\
365\end{array}$ & $\begin{array}{l}750 \\
792\end{array}$ & $\begin{array}{l}706 \\
695\end{array}$ & $\left.\begin{array}{l}73 \circ \\
564\end{array}\right\}$ & \pm 129 \\
\hline & Difference & -17 & -103 & -107 & +42 & - II & -166 & - \\
\hline \multirow{2}{*}{$\begin{array}{l}\text { Adrenal RNA } \\
(\mu \mathrm{g} \mathrm{P})\end{array}$} & Adequate & I I.7 7 & I $2 \cdot 9$ & 13.9 & $20 \cdot 2$ & 20.9 & $22 \cdot I\}$ & $\pm 2 \cdot 5$ \\
\hline & Difference & $\begin{array}{r}11 \cdot 4 \\
-0 \cdot 3\end{array}$ & $-2 \cdot 7$ & $\begin{array}{r}10.4 \\
-3.5\end{array}$ & $\begin{array}{r}17 \cdot 5 \\
-2 \cdot 7\end{array}$ & $\begin{array}{r}20.3 \\
-0.6\end{array}$ & $\begin{array}{l}10.4 J \\
-3.7\end{array}$ & 一 \\
\hline
\end{tabular}

$(P<0.05)$. Table 2 shows that this effect of diet was due to differences occurring in animals receiving the additional carbohydrate and fat. For the weight of the gland it was possible to establish this statistically by obtaining a significant interaction $(P<0.01)$ between the effects of protein intake and of calorie intake. Administration of ACTH caused a significant increment $(P<0.01)$ in the weight of the gland and of all of its constituents except DNA. This effect of ACTH administration did not show a significant interaction with the protein and calorie content of the diet, and in consequence it cannot be claimed on the basis of these results that the sensitivity of the gland to this hormone is altered by diet. However, inspection of the results obtained for the phospholipid content of the gland suggests a less effective increase when ACTH was given to animals receiving the protein-free diet, and this interaction almost attained significance at the $5 \%$ level.

The magnitude of the changes produced by protein deficiency and by ACTH administration in the weight of the gland and in the amounts of individual constituents 
is shown in Fig. I as percentages of the amounts of these constituents found in the control groups of animals receiving the protein-containing diet. For this purpose only the results obtained for protein-deficient animals receiving additional carbohydrate or fat have been used, since the effects of protein deficiency were confined to these groups. The losses of weight of the adrenal glands and of their chemical components during protein deficiency were proportionately much greater than the small reduction in body-weight. However, individual constituents of the gland differed in the magnitude of their response to protein deficiency, the reduction in DNA content being proportionately much less than that of the other constituents of the gland and of gland weight. After administration of ACTH, all the gland constituents except DNA responded with increments which were proportionately similar.

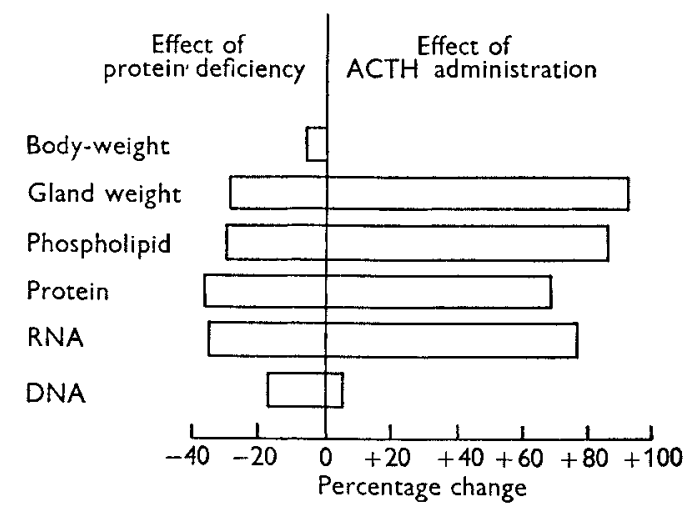

Fig. I. Percentage changes in the weights of the adrenal glands of rats, and their total content of phospholipid, protein, ribonucleic acid (RNA) and deoxyribonucleic acid (DNA) after administration of adrenocorticotrophic hormone (ACTH) for 3 days and after giving a protein-free diet for I I days. The values were calculated from the results given in Table 2. In order to compute the change due to ACTH administration, the results for all three calorie groups receiving the adequate intake of protein were combined and the increase in each component due to ACTH administration was calculated as a percentage of the amount found with the animals not receiving ACTH. In order to obtain the change due to protein deficiency, the groups receiving extra carbohydrate and extra fat without ACTH were combined at each protein level and the alterations in adrenal composition due to protein deficiency were calculated as percentages of the amounts present in the glands of the corresponding animals receiving the adequate protein intake. For comparison, the percentage reduction in the body-weights of these animals due to the protein-free diet has been included in the diagram.

The difference between the behaviour of DNA and of the other adrenal constituents during protein deficiency was confirmed by computing the amounts of these compounds in relation to DNA. Since the DNA content of an organ can be taken as a measure of cell number (Davidson \& Leslie, 1950; Thomson, Heagy, Hutchison \& Davidson, 1953), this method of expressing the results indicates whether changes in diet and administration of ACTH affect the composition of the average adrenal cell. Table 3 shows that both factors influenced the total weight of tissue per cell; analysis of variance confirmed that the changes produced by protein depletion and by ACTH administration were significant $(P<0 \cdot 0 \mathrm{I})$ and it was also found that the effect of dietary protein differed significantly according to the calorie content of the diet $(P<0.02$ for interaction). The amount of phospholipid per cell was also significantly 
affected by protein level and by ACTH administration $(P<0.01)$, but the action of ACTH was significantly greater when the diet contained protein $(P<0.02$ for interaction). Protein deficiency failed to cause a significant reduction in the protein content per cell $(P>0.05)$, but the increase after ACTH administration was significant $(P<0.01)$; the magnitude of the response to ACTH was uninfluenced by diet $(P>0.05$ for interaction). The RNA content per cell was significantly affected by the protein content of the diet and by ACTH administration $(P<0.01)$, but no interaction between these two effects or with calorie intake was estabished $(P>0.05)$. Thus these results indicate that the composition of the average adrenal cell was altered by protein deficiency and by ACTH administration; with phospholipid, a significant influence of protein intake on the capacity to respond to ACTH was also established.

\section{DISCUSSION}

The effect of a subnormal intake of protein on the adrenal gland has been investigated by only a few workers. In all instances (Limson \& Jackson, 1932; Orton, 1937; Leathem, I958), prolonged administration ad lib. of protein-deficient diets to growing rats failed to cause a diminution in the weight of the adrenal glands relative to bodyweight. Our own experiments were carried out on more mature rats and the period of protein deficiency was restricted to 5 or I I days, which is sufficient with this diet to produce marked changes in the chemical constituents of the liver (Munro \& Naismith, I953). When the rats received enough calories, the protein-free diet caused a considerable reduction in adrenal weight, which was of much greater magnitude than the small loss in body-weight produced by the short period of protein deficiency (Tables I and 2). No effect of protein intake on adrenal weight was observed when the calorie intake of the animals was low (Table 2 ).

Protein deficiency led to a decrease in the amount of individual chemical constituents of the adrenal gland (Tables I and 2). Deficiency of protein in the diet for II days caused a significant decrease in the total amounts of phospholipid, protein, RNA and DNA in the gland. Mandel, Jacob \& Mandel (1954) have also reported a loss of RNA and DNA from the adrenal glands during prolonged protein deficiency. The reduction in DNA content indicates a diminution in the number of cells in the gland. However, this decrease in cell population was insufficient to account for the amounts of the other constituents lost during protein deficiency in our studies. By calculating the total weight and the phospholipid, protein and RNA content of the gland in relation to DNA as a measure of cell number (Table 3 ), it was confirmed that protein deficiency leads to depletion of cellular constituents as well as to loss of cells.

The administration of ACTH caused a considerable increase in the amounts of all constituents of the gland except DNA (Tables I and 2). An increment in DNA content has, however, been observed after prolonged administration of ACTH to young rats (Fiala, Sproul \& Fiala, I956). The magnitude of the increase in total constituents after ACTH administration was not significantly influenced by the protein or calorie content of the diet (Tables $x$ and 2). However, when the individual constituents per cell were computed, DNA being used as a measure of cell number 
('Table 3), the increase in phospholipid per cell in response to ACTH administration was found to be significantly less for rats receiving no dietary protein. Other investigators have published conflicting reports of the influence of diet on the action of ACTH. Dontigny, Hay, Prado \& Selye (1948) found a greater response of the adrenal gland to injection of a crude anterior pituitary extract when the protein content of the diet was raised, but this effect was later shown to be dependent on some factor in the crude pituitary extract which stimulated release of ACTH from the pituitary gland of the recipient (Henriques, Henriques \& Selye, 1949). Experiments with purified ACTH failed to demonstrate any influence of dietary protein level on the response of gland size to this stimulus (Ingle, Prestrud, Li \& Evans, I947; Moya, Prado, Rodriguez, Savard \& Selye, 1948). However, our findings show that the phospholipid content of the adrenal gland may provide a more sensitive index of impaired response to ACTH.

Since the responses of most constituents of the adrenal gland to ACTH administration are not affected by protein depletion (Tables $\mathrm{I}-3$ ), it can be concluded that the reduced amounts of these constituents observed after giving a protein-free diet are not due to impaired capacity of the adrenal gland to synthesize them. This implies that the defect in the protein-depleted animal is a diminished secretion of endogenous ACTH from the pituitary gland. This conclusion is supported by studies made on animals with a low protein intake and subjected to the stress of subtotal nephrectomy (Handler \& Bernheim, 1950) or chronic undernutrition (Selye, 1950). In both investigations it was concluded that in states of protein deficiency the pituitary gland secretes less ACTH.

\section{SUMMARY}

I. The weights and chemical constituents of the adrenal glands of mature female rats were measured after a protein-free diet had been given for 5 or I I days. The effect of adrenocorticotrophic hormone administration on the adrenal glands of normal and of protein-deficient animals was also compared.

2. Protein deficiency caused a reduction in the weight of the gland and a diminution in its total content of phospholipid, protein and ribonucleic acid, which was proportionately much greater than the loss of body-weight caused by the diet administered. After the longer period of protein deficiency, there was also a significant reduction in the total amount of deoxyribonucleic acid in the adrenal gland, indicative of a loss of cells. However, the reductions in other gland constituents were proportionately greater than that of DNA, from which it was concluded that the proteinfree diet caused depletion of the individual cells in addition.

3. The adrenal glands of the protein-deficient animals responded to administration of ACTH with a large increase in weight and in content of phospholipid, protein and RNA but not of DNA. The increment in phospholipid content was significantly less than that obtained by injecting ACTH into animals receiving protein in the diet.

4. It is concluded that the size and individual components of the adrenal gland diminish during protein deficiency mainly because of reduced secretion of ACTH by the anterior pituitary gland. 


\section{REFERENCES}

Benua, R. S. \& Howard, E. (1945). Endocrinology, 36, г7o.

Ceriotti, G. (1952). F. biol. Chem. r98, 297.

Davidson, J. N. \& Leslie, I. (1950). Cancer Res. ro, 587.

Dontigny, P., Hay, E. C., Prado, J. L. \& Selye, H. (1948). Amer. F. med. Sci. 215, 442.

Fahr, T. (1912). Verh. dtsch. path. Ges. $\mathbf{r}_{5}, 234$.

Fiala, S., Sproul, E. E. \& Fiala, A. E. (1956). 7. biophys. biochem. Cytol. 2, I 15.

Griswold, B. L., Humoller, F. L. \& MeIntyre, A. R. (1951). Analyt. Chem. 23, 192.

Handler, P. \& Bernheim, F. (1950). Amer, F. Physiol. 162, 368.

Henriques, S. B., Henriques, O. B. \& Selye, H. (1949). Endocrinology, 45, I 53.

Hutchison, W. C., Ramaiah, T. R., Neilson, F. J. \& Munro, H. N. (I960). Proc. Nutr. Soc. I9, xxiii. Ingle, D. J. (1945). Endocrinology, 37, 7 .

Ingle, D. J., Ginther, G. B. \& Nezamis, J. (1943). Endocrinology, 32, 410.

Ingle, D. J., Prestrud, M. C., Li, C. H. \& Evans, H. M. (1947). Endocrinology, 41, I70.

Kerr, S. E. \& Seraidarian, K. (1945). F. biol. Chem. 159, 2 1 I.

Kosterlitz, H. W. (1947). F. Physiol. ro6, I94.

Kovács, K. \& Korpássy, B. (1952). Acta physiol. Hungar. 3, 243.

Leathem, J. H. (1945). Endocrinology, 37, I 57.

Leathem, J. H. (1947). Proc. Soc. exp. Biol., N.Y., 64, 90.

Leathem, J. H. (1951). Exp. Med. Surg. 9, 138.

Leathem, J. H. (1958). Rec. Progr. Hormone Res. I4, I4I.

Limson, M. \& Jackson, C. M. (1932). F. Nutr. 5, I63.

Mandel, P., Jacob, M. \& Mandel, L. (1954). C.R. Acad. Sci., Paris, 238, 288.

Moya, F., Prado, J. L., Rodriguez, R., Savard, K. \& Selye, H. (1948). Endocrinology, 42, 223.

Munro, H. N. (1949). F. Nutr. 39, 375.

Munro, H. N. \& Naismith, D. J. (1953). Biochem. F. 54, r9r.

Orton, A. U. (1937). Quoted by Tepperman, Engel \& Long (1943).

Paul, J. (1958). Analyst, 83, 37.

Schmidt, G. \& Thannhauser, S. J. (1945). F. biol. Chem. 16r, 83.

Selye, H. (1950). The Physiology and Pathology of Exposure to Stress, p. 324. Montreal: Acta, Inc.

Tepperman, J., Engel, F. L. \& Long, C. N. H. (1943). Endocrinology, 32, 403.

Thomson, R. Y., Heagy, F. C., Hutchison, W. C. \& Davidson, J. N. (1953). Biochem. F. 53, 460.

Tuchmann-Duplessis, H., Aschkenasy-Lelu, P. \& Aschkenasy, A. (1948). C.R. Acad. Sci., Paris, 226, 5 I 8 . 